\title{
Effects of the Flipped Classroom on Understanding the Thermodynamic Concept at High School Students
}

\author{
Khusnul Basriyah ${ }^{1, *}$, Dwi Sulisworo ${ }^{1}$, Guntur Maruto ${ }^{1}$, Moh Toifur ${ }^{1}$, Nurul Huda Abd Rahman ${ }^{2}$ \\ ${ }^{1}$ Ahmad Dahlan University, Indonesia \\ ${ }^{2}$ Faculty of Education \& Teaching, University Pendidikan Sultan Idris, Malaysia
}

Received August 8, 2019; Revised October 6, 2019; Accepted February 20, 2020

Copyright $\odot 2020$ by authors, all rights reserved. Authors agree that this article remains permanently open access under the terms of the Creative Commons Attribution License 4.0 International License

\begin{abstract}
This study explains the increase in 11thgrade student achievement on the thermodynamic subject with a flipped classroom approach that was assisted by learning animation videos developed using Powtoon application. This research was a quasi-experimental design with a pretest-posttest control group design. The sample of this study was two classes from five classes of 11th-grade students. Instruments for collecting data on achievement used test instruments in the form of multiple choices. Nontest instruments in the form of questionnaires with a Likert scale were used to measure student learning motivation and numeric abilities. The statistical analysis techniques were T-test, ANOVA, and linear regression. The results of this study found that there was an increase in student achievement between before and after being taught with flipped classroom learning models assisted by learning animation videos. Also, there were also significant differences in achievement between students taught with flipped classroom learning models supported by learning animation videos compared to students who were taught conventionally. In this study numerical abilities can be used as predictors. The contribution of numerical ability to students who were taught with flipped classroom models was higher than in another group. The limitation of this study is that this study did not pay attention to the strategies paired on the development of animated videos. The selection of learning strategies that are attached to the animated video will be used to determine the effect on learning. In general, research on the flipped classroom does not emphasize the type of video used. This study highlights the attractiveness of the animation made in the learning video.
\end{abstract}

Keywords Animation Video, Flipped Classroom, Learning Media, Achievement, Learning Strategy, Physics Learning

\section{Introduction}

The 21st century is known as the century of openness or globalization meaning that human's life in the 21st century experiences a fundamental change. It is different from the life's system in the previous century when learning process was still teacher-centered while learning in the 21 st century requires learner-centered learning [1,2]. In the learning process, the objectives are not only achievement but the process experienced by students [3,4]. The process is indeed not a difficult challenge for students because they frequently encounter difficulties in the learning process.

One of the difficulties the students frequently have in the learning process is the difficulty in finishing the homework given by the teacher. Physics is one of the subjects closed to the mathematical operation such as algorithmic translation, fraction, linear and derivative. Also, physics also needs a high capability to think and analyze both numerically and abstractly. Thus, the numeric ability is a factor that can influence a student's physics achievement [5]. Students with excellent numeric capabilities could finish assignments or homework given by their teacher easily [6]. On the contrary, for students with the lack of numeric capability, finishing homework individually is one challenge.

Among the many factors leading to the success of the learning process is motivation [7]. It is an internal situation awakening, directing, and sustaining attitudes [8]. With learning motivation, students have learning positions; they will be addressed and will improve achievement9,10]. Therefore, this is a strategy to enhance student's learning achievement.

Bringing the homework to school may be easier for the students with the low numeric capability to solve questions because at school they can ask friends or teachers so that they can do exercises or other activities such as debate, presentation, and discussion. The more activities, the more significant influence the students will get to improve their learning achievement. 
Taking homework to school and finishing it at school is similar to the model of the flipped classroom [11]. In this learning model, students learn materials in the forms of videos or e-books at home before their learning starts [12]; therefore, in the classroom, the teacher does not explain materials. The teacher only plays a role as a facilitator at the school. The result of a research on flipped classroom showed that there is the improvement of achievement for flipped classrooms compared to conventional classrooms $[13,17]$. Flipped classroom changes the student's learning strategies in the classroom which is replacing the teachinglearning process and the role of a teacher that is usually carried out at school. Now students watch the learning videos at home; therefore, engaging in learning media is needed to make sure that the students study at home.

One of the media used in the teaching-learning process with the flipped classroom model is audiovisual learning media. Such media are not only listened but also watched. Powtoon is a creator of software of animation, presentation, and video that is very fun because a cartoon supports it on the application [18]. The research on Powtoon shows that it is useful to improve learning achievement, encourage cognitive student motivation, enhance student's memorization and understand aspects. The characteristic on the flipped classroom is its learning video, so the researchers choose Powtoon as the learning media and the material used is Thermodynamic. Thermodynamic is selected because this material is rarely practiced and hard for students. It is expected that the students can understand the content through the visual process.

However, the use of Powtoon in thermodynamic learning is not yet universal. The researchers implemented Powtoon media so that student's achievement improved. In learning, not only learning strategies can affect learning performance. In physics learning, not only learns about concepts but also determines number manipulation to be used in applying formulas. There are many other factors influencing learning performance to support this ability, namely students' numerical skills. Also, motivation is a well-known factor that influences learning performance. In this study, to ensure that only learning strategies can affect learning performance, numerical ability and motivation are used as control variables.

This research aims to determine the influence of student's motivation on learning Thermodynamic, numeric ability towards achievement; and to evaluate the effectiveness of learning by using the Flipped Classroom learning model with Powtoon

\section{Methods}

\subsection{Research Context}

The research was a quasi-experimental design with a posttest-only controlled group design. The population of the study was all eleventh-grade students of a state senior high school in Yogyakarta. The sampling technique was random cluster sampling. Two classes with the total number of 70 students were used as the samples assigned as experimental group and control group.

There were three variables in this research. The independent variable was the learning strategy (IVAR). The dependent variable was learning achievement (DVAR), and the covariates were numeric capability (COV1) and motivation (COV2).

The test was administered to collect the data. Concerning the instrument, the test consisted of 30 questions (25 questions were multiple choices, and five were in essay type). All the items tested were reliable, and in term of difficulty level, among the 30 questions (14 items were easy, and 16 items were fair).

Further, the researcher used posttest to measure the students' achievement. Non-test instruments were used for measuring student's motivation by using student's independency questionnaires and numeric capability by using intelligence and Talent Test for arithmetic and number. The researchers checked the instruments before using them in the validity test, the reliability test, and the difficulty level test. To analyze the data, on the result of posttest the researchers employed T-test, ANCOVA test, and Lin-ear regression.

\subsection{Learning Activity}

The flipped classroom is learning that reverses between classroom learning and homework. Students see short videos related to teaching the material at home before they study in class. In class students learn by discussing, working on projects or contextual exercising activities. In classroom learning, for the experimental group, the teacher invites students to discuss, so that critical thinking skills emerge. The teacher in this activity discusses problems or issues related to thermodynamic material and links this concept to solve mathematical problems. Thus students not only memorize formulas but can explain this formula with particular phenomena. Table 1 summaries the activity of each group.

Table 1. Activity between group

\begin{tabular}{|c|c|c|}
\hline Groups & At home & In-class \\
\hline $\begin{array}{c}\text { Conventional } \\
\text { lectures } \\
\text { (Control group) }\end{array}$ & $\begin{array}{c}\text { Solving problems } \\
\text { (homework) }\end{array}$ & $\begin{array}{c}\text { Listening to lecture } \\
\text { (direct lesson) }\end{array}$ \\
\hline $\begin{array}{c}\text { Flipped } \\
\text { classroom } \\
\text { (Experiment } \\
\text { group) }\end{array}$ & $\begin{array}{c}\text { Listening to lecture } \\
\text { (short video) }\end{array}$ & $\begin{array}{c}\text { Solving problems } \\
\text { (learning activity) }\end{array}$ \\
\hline
\end{tabular}

The mechanism or the procedure of the implementation of the flipped classroom learning model is:

- The teacher prepares and provides a short video created using Powtoon that students will watch and learn about at home. 
- Students watch the video and learn the instructions given by the teacher through the video so that they are familiar with the concepts and material that will be presented at the next meeting.

- In the classroom, students work on tasks based on instructions that have been delivered previously via video. In this case, students can focus more on the difficulties in understanding the material or its ability to solve problems related to the content.

- The teacher acts as a facilitator who accompanies students in working on the task.

\section{Result}

\subsection{The Powtoon Video}

There are three videos made to support this learning. Each video contains different material. Media developed with Powtoon that has characteristics of dynamic videos that can attract student interest. There are three main activities in each video which are studying physics concepts, critical thinking to solve contextual problems, and building knowledge of the concepts learned. Students learn independently when watching material through this video, so it is possible that there is still a lack of understanding or misconception. This lack of knowledge is corrected when students are in class.

Three videos produced to support this learning activity are

- The video explains the first law of thermodynamics that covers systems and the environment, works and internal energy.

See http://youtube.be/WG_m_rZ55LLg.

- The video explains the second law of thermodynamics including the Carnot cycle and the Coolant Engine. See http://youtube.be/uMm1ZGmOHIU.

- The video describes processes in thermodynamic gases such as isothermic, isobaric, and adiabatic. See http://youtube.be/g_IVEdYDW34.

\subsubsection{Learning the Physics Concept}

The concept is explained using audio that accompanies text or images or motion images. The teacher uses simple language to be quickly understood by students. The teacher also provides several examples in everyday life related to the concept. Figure 1 is the sample of the screenshot representing the Carnot cycle concept.

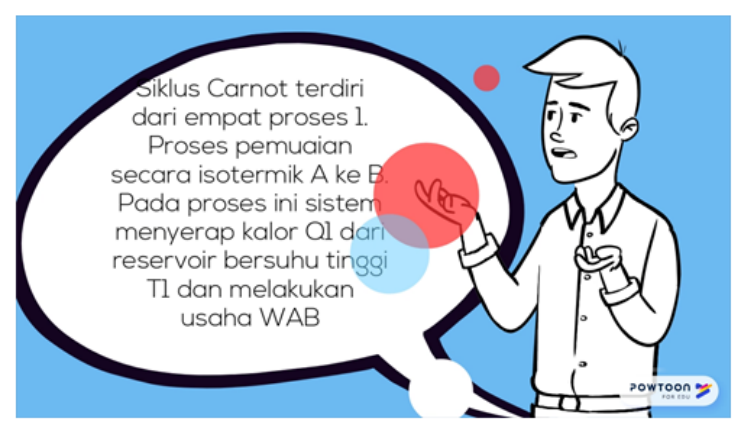

Figure 1. A part of the video explaining the Carnot cycle. The technique was teacher describe and explain the theory using text and audio

\subsubsection{Critical Thinking Activity}

After students learn the material, they are given a case or problem-related to a particular concept. The teacher conveys the problem and asks students to think about the solution. The teacher presents the issue in several forms such as text, picture, or video. Students can repeat this video again to reach an understanding of the concept and be able to solve the problem given by the teacher. Figure 2 and Figure 3 show the example of the issue in the video.

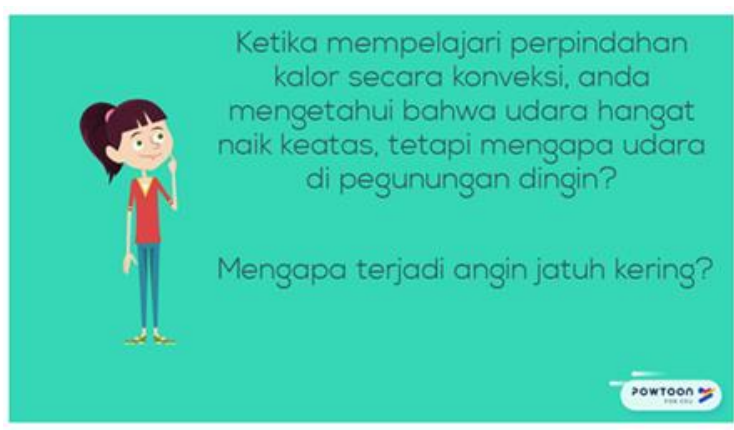

Figure 2. A part of the video explaining the heat transfer. The technique is contextual learning. The teacher asked the student to think critically of phenomena of heat transfer in daily life.

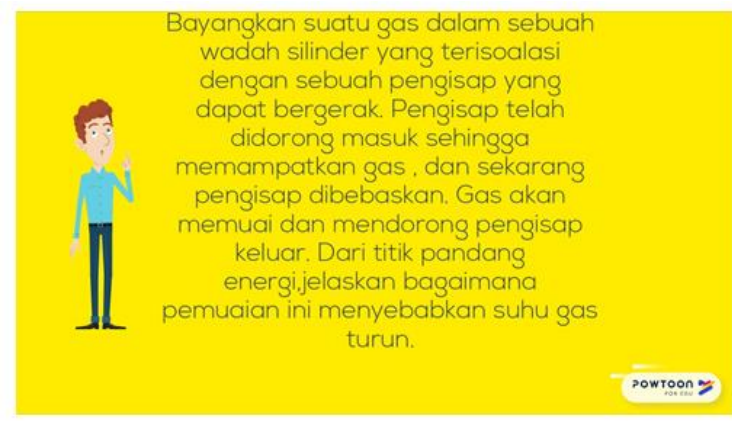

Figure 3. In this part of the video, the teacher asked the student to solve the problem of a simple system that used the heat transfer theory. 


\subsubsection{Building the Knowledge}

The understanding as the achievement in this learning includes being able to explain thermodynamic concepts, can use formulas to solve thermodynamic cases, and be able to analyze phenomena in daily life related to this material. To integrate these outcomes, in the video several examples were given related to the application of formulas and explanations.

\subsection{Media Validation}

\subsubsection{Learning Subject Validation}

Validated aspects related to the subject matter include the accuracy of the concepts described in the video (accuracy of the concept), the depth of the material taught in video (depth of the concept), the possibility of videos to support understanding concepts with several strategies provided (mastery of the concept) and video capabilities to explain the application of concepts in implementation. The results of the material expert validation are shown in Figure 4. From this figure, in all aspects, the validators give values above $75 \%$. This score is in an excellent category.

Validated aspects related to the subject matter include the accuracy of the concepts described in the video (accuracy of the concept), the depth of the material taught in video (depth of the concept), the possibility of videos to support understanding concepts with several strategies provided (mastery of the concept ) and video capabilities to explain the application of concepts in implementation. The results of the material expert validation are shown in Figure 4. From this figure, in all aspects, the validators give values above $75 \%$. This score is in an excellent category.

\subsubsection{Media Validation}

As a learning medium, the videos made are validated in aspects of clarity of sentence, language, physical appearance, sound, picture, and functionality to the usage. The highest score given by the three validators is on the feasibility of the usage aspect. This finding supports the assumptions used that Powtoon is an excellent application software for use in making learning media. With the score given by the three validators, this video is in a good category (see Figure 5).

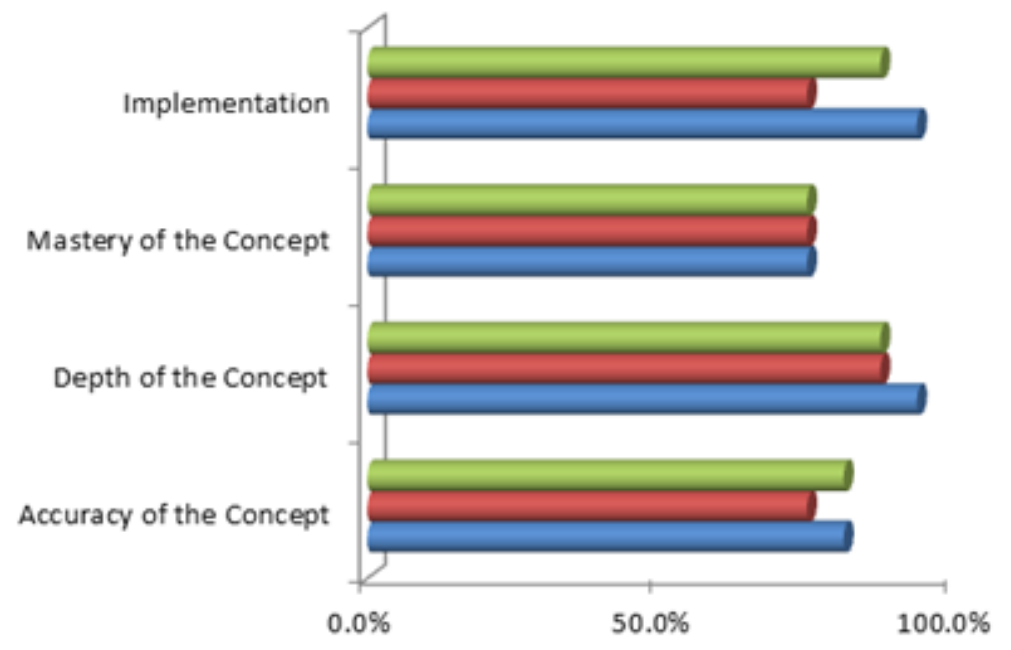

m subject expert 3 m subject expert 2 m subject expert 1

Figure 4. The result of the learning validation 


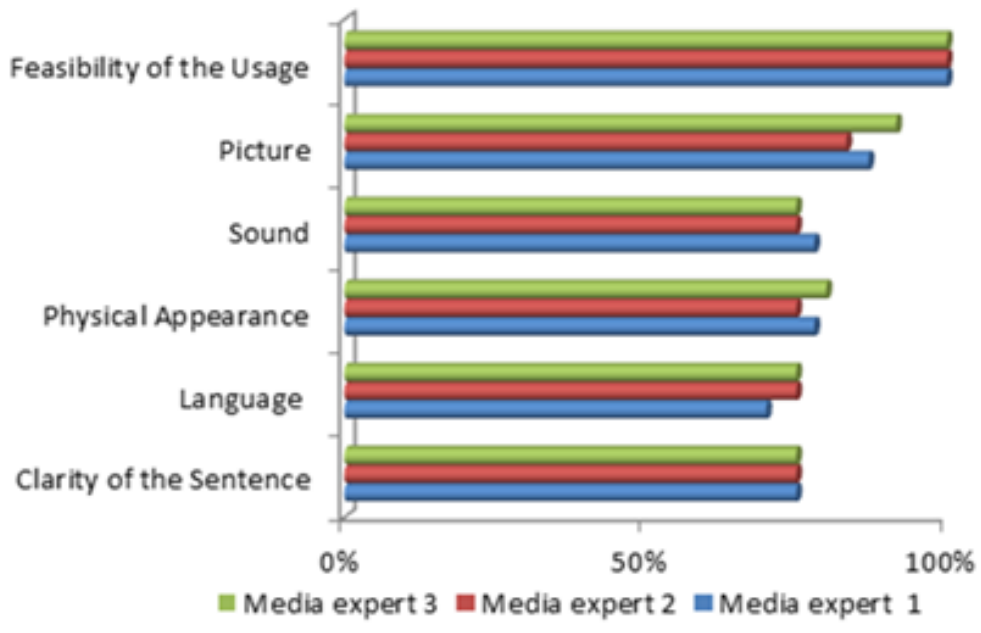

Figure 5. The result of the media validation

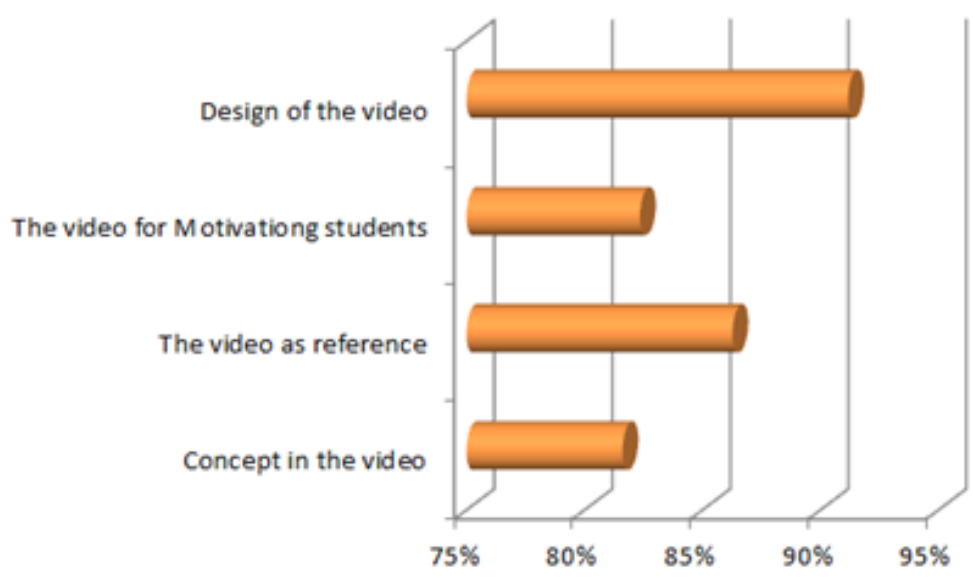

Figure 6. The trial result of the video

\subsection{The Student's Response to the Video}

The learning media developed in this research is video in Powtoon application as a student's learning materials at home. The quality of the learning media is categorized feasible as learning media with evaluation from the materials expert, and the media expert after validation, we tested this media to 30 students. There are four aspects to be considered: the concept in the video $(81.62 \%)$, video as reference materials $(86.27 \%)$, motivating students $(82.35 \%)$, and video design (91.18\%). Figure 6 shows this result. In general, based on this percentage, the video is feasible to be used in learning.

\subsection{Statistical Analysis}

\subsubsection{Ancova}

Before analyzing with ANCOVA, we analyze the descriptive statistics from the results of the study. Table 2 shows the analysis. From Table 1, the experimental group (CL1) had a higher average learning outcome (76.67) than one (67.17) of the control groups (CL2). The standard deviation value (CL1) has a smaller standard deviation (8.34) than one (11.35) of (CL2).

Table 2. Descriptive statistic

\begin{tabular}{|c|c|c|c|}
\hline \multicolumn{3}{|c|}{ Dependent Variable:Learning Achievement } \\
Independent Variable & Mean & Std. Deviation & N \\
\hline Experiment group & 76.6667 & 8.33908 & 30 \\
\hline Control group & 67.1667 & 11.34744 & 30 \\
\hline Total & 71.9167 & 10.97345 & 60 \\
\hline
\end{tabular}

To find out the increase of achievement of the experimental class and control class, and the correlation between motivation, numeric capability on thermodynamic learning, ANCOVA test was employed. Before the analysis, prerequisite condition analysis was carried out such as normality test and homogeneity test. On the normality test of pretest and posttest data, numeric capability and motivation data were normally distributed, and so were the data on homogeneity test; the data were homogenous. The result of ANCOVA analysis is represented in Table 3. 
T-test analysis was used to determine the significant difference in the result of numeric capability, posttest and motivation between experimental group and control group. The result is that there is a difference in achievement between the experiment group and the control group with a significance level of 0.05 . It means that there is a significant difference in numeric capability between experimental group and control group. On motivation covariate, the significant result is less than the significance level 0.05 . Thus, there is a considerable difference in learning motivation between experimental classes and control classes.

Table 3. Tests of Between-Subjects Effects

\begin{tabular}{|c|c|c|c|c|c|}
\hline \multicolumn{5}{|c|}{ Dependent Variable: Learning Achievement (DVAR) } \\
\hline Source & $\begin{array}{c}\text { Type III } \\
\text { Sum of } \\
\text { Squares }\end{array}$ & df & $\begin{array}{c}\text { Mean } \\
\text { Square }\end{array}$ & F & Sig. \\
\hline $\begin{array}{c}\text { Corrected } \\
\text { Model }\end{array}$ & $6032.805^{\text {a }}$ & 3 & 2010.935 & 105.071 & .000 \\
\hline Intercept & 1513.054 & 1 & 1513.054 & 79.056 & .000 \\
\hline COV1 & 4435.499 & 1 & 4435.499 & 231.753 & .000 \\
\hline COV2 & 39.164 & 1 & 39.164 & 2.046 & .158 \\
\hline Class & 1156.423 & 1 & 1156.423 & 60.423 & .000 \\
\hline Error & 1071.778 & 56 & 19.139 & & \\
\hline Total & 317425.000 & 60 & & & \\
\hline Corrected Total & 7104.583 & 59 & & & \\
\hline a R Squared = .849 (Adjusted R Squared =.841) & & \\
\hline
\end{tabular}

\subsubsection{Variable Contribution}

Predictor contributions (COV1 and COV2) can be seen in relative contributions and effective contributions. Linear regression analysis can be used to find out both types of contribution. The sum of the effective contributions of these two covariates is the same as the R square value or the coefficient of determination. The relative contribution is the magnitude of predictor contribution to the square of regression. Table 4 shows the result of the linear regression analysis for the experimental group.

\begin{tabular}{|c|c|c|c|c|c|c|}
\hline & \multirow{2}{*}{ Model } & \multicolumn{2}{|c|}{$\begin{array}{l}\text { Unstandardized } \\
\text { Coefficients }\end{array}$} & \multirow{2}{*}{$\begin{array}{c}\begin{array}{c}\text { Standardized } \\
\text { Coefficients }\end{array} \\
\text { Beta }\end{array}$} & \multirow{2}{*}{$\mathrm{t}$} & \multirow{2}{*}{ Sig. } \\
\hline & & B & Std. Error & & & \\
\hline \multirow{3}{*}{1} & (Constant) & -117.536 & 36.916 & & -3.184 & .004 \\
\hline & COV1 & 1.847 & .319 & .734 & 5.784 & .000 \\
\hline & COV2 & -.119 & .120 & -.126 & -.993 & .329 \\
\hline
\end{tabular}

Table 5 shows the correlation coefficients of each variable to others.

Table 5. The correlation coefficient

\begin{tabular}{|c|c|c|c|c|}
\hline & & DVAR & COV1 & COV2 \\
\hline \multirow{3}{*}{ Pearson Correlation } & DVAR & 1.000 & .742 & -.172 \\
\cline { 2 - 5 } & COV1 & .742 & 1.000 & -.063 \\
\cline { 2 - 5 } & COV2 & -.172 & -.063 & 1.000 \\
& DVAR &. & .000 & .181 \\
Sig. (1-tailed) & COV1 & .000 &. & .370 \\
\cline { 2 - 5 } & COV2 & .181 & .370 &. \\
\hline \multirow{3}{*}{$\mathrm{N}$} & DVAR & 30 & 30 & 30 \\
\cline { 2 - 5 } & COV1 & 30 & 30 & 30 \\
\cline { 2 - 5 } & COV2 & 30 & 30 & 30 \\
\hline
\end{tabular}

The model summary of this case that is used to calculate the COV1 and COV 2 contribution shows that the R-square is equal to .657 and $\mathrm{R}$ is equal to .753 . These numbers are used to calculate the relative contribution of the independent variable to the dependent variable. The final calculation of the contribution is in Table 6.

Table 6. Contribution of covariates towards dependent variable

\begin{tabular}{|c|c|c|c|c|}
\hline Variable & Regression Coefficient & Correlation & Effective Contributibution & Relative Contribution \\
\hline COV1 & 0.734 & 0.742 & 54.4628 & 96.0543 \\
\hline COV2 & -0.126 & -0.172 & 2.1672 & 3.8222 \\
\hline
\end{tabular}


The contribution value in Table 4 shows that COV1 has a higher contribution to DVAR than COV2. This value means that COV1 is a better predictor to estimate DVAR than COV2. If you look at the total effective contribution (56.62), there are other variables that affect DVAR equal to (43.38) which cannot be explained in this study.

\section{Discussion}

Based on the result of the ANCOVA, there is no significant influence between motivation covariate and learning achievement, but for numeric capability, it is very substantial for student's learning achievement. Therefore, it can be concluded that motivation does not influence learning achievement, while numeric ability has a significant influence towards this research.

In the experimental class, it appears that there is a contribution of numeric capability and motivation towards learning achievement. The total of effective contribution is $56.63 \%$ which means there are $43.7 \%$ other variables that can influence the dependent variable. The number of effective contribution and the relative contribution of numeric capability towards learning achievement were $56.63 \%$ and $96.17 \%$ respectively. The numeric ability gave the highest contribution to the posttest score of student's learning achievement. Also, the number of effective contribution and the relative contribution of motivation towards learning achievement are $2.16 \%$ and $3.82 \%$ respectively. Motivation in this research contributes less towards the posttest score of student's learning achievement.

For the control class, there is a contribution of numeric capability and motivation towards learning achievement. The total number of effective contribution is $96.21 \%$, which means that $3.78 \%$ of other variables are the number of influence on the dependent variable. The amount of effective contribution of the numeric capability towards learning achievement is $95.15 \%$, while the one of relative contribution is $98.9 \%$. The numeric ability gives the highest contribution towards the posttest score of student's learning achieve-ment achievement. Meanwhile, the number of the effective contribution of motivation towards learning achievement is $1.05 \%$, and the one of relative contribution is 1.09. The score of motivation in this research, in fact, gives a small contribution to the posttest score of student's learning achievement.

The value of numerical ability in this study gives the highest contribution to the posttest score of student achievement. This skill is followed by the review of numerical skills. Students who have excellent numerical skills can efficiently complete assignments or homework given by their teachers [19]. Flipped classrooms require significant effort for the preparation of videos created by the teacher. However, the results obtained provide high benefits for students in improving achievement. The scenario in the video that designed with specific sequences can be used to encourage the achievement of learning competencies [20,21].

Learning with flipped classroom assisted videos shows a positive impact on improving students' achievement. We want to highlight some of the factors based on the results of this study. There are still other factors besides numerical ability and interest in learning that have a significant influence on students' learning success. These factors will be related to the characteristics of teaching material, student characteristics, types and levels of competencies that must be achieved, and learning strategies are developed by the teacher [22,23]. Issues related to how to build a conducive learning atmosphere in the classroom when students carry out learning activities after learning from videos need to be studied more deeply to be able to know more comprehensively in explaining the ability of flipped classroom to improve achievement [24,25]. Although there have been many studies related to the flipped classroom, there are still many research opportunities associated with this strategy related to the development of information and communication technology like how to use flipped classroom in online learning. There are also other studies on variables that affect achievements previously discussed.

\section{Conclusions}

Learning media developed with Powtoon applications have good potential to improve student achievement in physics learning with flipped classroom models. This potential is shown in videos that use simple language, associated with issues and examples encountered in everyday life, combining learning with concepts and numerical skills. In this study, achievement has been measured in understanding concepts and critical thinking skills. It's just that the two factors are not analyzed separately. Further analysis will be able to find out how this flipped classroom has an impact on broader aspects of learning.

\section{Acknowledgements}

This research is funded by the Ministry of Research, Technology and Higher Education of the Republic of Indonesia under Post-graduate Research Grant Scheme, the Year 2019.

\section{REFERENCES}

[1] I. Galindo. Flip your classroom: reach every student in every class every day, Teaching Theology \& Religion, Vol. 17, No. 1, 82-83, 2014. 
[2] M. B. Gilboy, S. Heinerichs, G. Pazzaglia. Enhancing student engagement using the flipped classroom, Journal of nutrition education and behavior, Vol. 47, No. 1, 109-144, 2015.

[3] A. M. AL-Zahrani. From passive to active: the impact of the flipped classroom through social learning platform on higher education student' creative thinking, British Journal of Education Technology, Vol. 46, No. 6, 133-1148, 2015.

[4] N. T. T. Thai, B. De Wever, M. Valcke. The impact of a flipped classroom design on learning performances in higher education: Looking for the best 'Blend' of lectures and guiding questions with feedback, Computer and Education, Vol. 107, 113-126, 2017.

[5] A. Lipton, G. J. Huxham, D. Hamilton. Predictors of success in a cohort of medical students, Medical Education, Vol. 18, No. 4, 203-210, 1984.

[6] A. K. Badru. Problem-based instructional strategy and numerical ability as determinants of senior secondary achievement in Mathematics, Journal of Education and Practice, Vol. 7, No. 13, 89-95, 2016.

[7] S. M. Glynn, L. P. Aultman, A. M. Owens. Motivation to learn in General Education Programs, The Journals of General of Education, Vol. 54, No. 2, 150-170, 2005.

[8] A. Woolfolk. Educational psychology (Tenth Edition), New York: Pearson Educational Inc., 2007.

[9] R. I. Arends, A. Kilcher. Teaching for student learning: becoming an accomplished teacher, New York: Routledge, 2010.

[10] P. K. Murphy, P. A. Alexander. A motivated exploration of motivation terminology, Contemporary Educational Psychology, Vol. 25, No. 1, 3-53, 2000.

[11] A. Roehl, S. L. Reddy, G. J. Shannon. The flipped classroom: An opportunity to engage millennial students through active learning strategies, Journal of Family \& Consumer Sciences, Vol. 105, No. 2, 44-49, 2003.

[12] L. Ching-pao, M. Chen Hai. The effects of flipped classroom on learning effectiveness: using learning satisfaction as the mediator, World Transactions on Engineering and Technology Education, Vol. 14, No. 2, 231-244, 2016.

[13] J. M. Cleveland. Flipped Classroom Learning in High School Physics, Thesis, Montana State University, 2017.

[14] G. Aşıksoy, F. Özdamlı F. Flipped classroom adapted to the ARCS model of motivation and applied to a physics course, Eurasia Journal of Mathematics, Science \& Technology Education, Vol. 12, No. 6, 1589-1603, 2016.

[15] R. Capone, M. R. DelSorbo, O. Fiore. A flipped experience in physics education using CLIL methodology, EURASIA Journal of Mathematics Science and Technology Education, Vol. 13, No. 10, 6579-6582, 2017.

[16] Z. Atwa, R. Din, M. Hussin. Effectiveness of flipped learning in physics education on Palestinian high school students' achievement, Journal of Personalized Learning, Vol. 2, No. 1, 73-85, 2016.

[17] R. Culbertson, H. Babb, J. Cunningham. The Effects of Combining a Flipped Classroom with Modeling Instruction in AP Physics Classrooms, Thesis, Arizona States
University, 2017.

[18] H. M. Pais, P. H. Nogués, B. R. Muñoz. Incorporating Powtoon as a learning activity into a course on technological innovations as didactic resources for Pedagogy Programs, International Journal Of Engineering and Technology, Vol. 12, No. 6, 120-131, 2017.

[19] B. O. Ogunleye, V. F. T. Babajide. Commitment to science and gender as determinants of students achievement and practical skills in physics, Journal of Science Teachers Association of Nigeria, Vol. 46, No. 1, 125-135, 2011.

[20] M. Rioseco, F. Paukner, B. Ramírez. Incorporating PowToon as a learning activity into a course on technological innovations as didactic resources for pedagogy programs, International Journal of Emerging Technologies in Learning (iJET), Vol. 12, No. 6, 120-131, 2017.

[21] W. Laaser, E. A. Toloza. The Changing Role of the Educational Video in Higher Distance Education, International Review of Research in Open and Distributed Learning, Vol. 18, No. 2, 264-275, 2017.

[22] Y. J. Lee, C. H. Chao, C. Y. Chen. The influences of interest in learning and learning hours on archievementof vocational college students in Taiwan: using a teacher's instructional attitude as the moderator, Global Journal Of Engineering Education, Vol. 13, No. 3, 140-153, 2011.

[23] N. L. Ennen, E. Stark, A. Lassiter. The importance of trust for satisfaction, motivation, and academic performance in student learning groups. Social Psychology of education, 18(3), 615-633. 2015, 2015.

[24] C. Greenhow, C. Lewin. Social media and education: Reconceptualizing the boundaries of formal and informal learning, Learning, media and technology, Vol. 41, No. 1, 6-30, 2016.

[25] W. H. Wu, Y. C. J. Wu, C. Y. Chen, H. Y. Kao HY, Huang SH. Review of trends from mobile learning studies: A metaanalysis, Computers \& Education, Vol. 59, No. 2, 817-827, 2012. 